\title{
Development of Local Art-based Drama Textbooks
}

\section{R. Soleh ${ }^{1}$, H. J. Waluyo², S. Y. Sudikan³, and N. E. Wardani²}

${ }^{1}$ Indonesian Language and Literature Education Study Program, Faculty of Teacher Training and Education, PGRI University of Madiun, Jalan Setia Budi No. 85, Madiun, East Java 63118, Indonesia ${ }^{2}$ Indonesian Language and Literature Education Study Program, Faculty of Teacher Training and Education, Sebelas Maret University, Jalan Ir. Sutami No. 36A, Surakarta, Central Java 57126 Indonesia

${ }^{3}$ Indonesian Language and Literature Education Program, Faculty of Languages and Arts, State University of Surabaya, Jalan Raya Kampus Unesa, Surabaya, East Java 60213, Indonesia

\section{Abstract}

The purposes of this research are: (1) to describe the recent learning of drama at LPTK, which includes describing the application of existing drama textbooks; (2) to describe the needs of lecturers and students associated with the improvement of

Corresponding Author:

D. R. Soleh

rohmansolehdwi@yahoo.com

Received: 6 April 2018

Accepted: 3 May 2018

Published: 26 July 2018

Publishing services provided by

Knowledge $\mathrm{E}$

(c) D. R. Soleh et al. This article is distributed under the terms of

the Creative Commons

Attribution License, which

permits unrestricted use and

redistribution provided that the

original author and source are credited.

Selection and Peer-review under the responsibility of the ISLLE 2017 Conference Committee. drama textbooks at LPTK; (3) to describe the development of drama textbooks based on local arts, including: (a) describing the development of a prototype (draft) into a drama textbook based on local arts using expert judgment, and (b) describing the development and improvement of drama textbooks based on local arts regarded to limited testing in the research field; (4) to describe the effective level of drama textbooks based on the local arts rather than conventional textbooks at LPTK; (5) to describe the dissemination of drama textbooks based on the local arts. The outcomes of this research are (1) learning devices including a syllabus and SAP, and (2) drama textbooks based on local arts.

Keywords: drama textbook, local arts

\section{Introduction}

Drama at LPTK, especially in the Indonesian Language and Literature Education Study Program IKIP PGRI Madiun, is a compulsory course for students and carries three credits. According to Waluyo [1], the teaching of drama can be divided into two kinds, i.e. the teaching of drama theory, or teaching the theory of drama texts (scripts), and teaching about the theory of staging drama.

Learning materials should also be tailored to the level of the particular school education. The higher the level of education, the more profound the material. These drama 
lessons include drama theory materials and drama appreciation materials. Drama theory is a theoretical handbook on what and how and for what drama. Appreciation material is in the form of drama scripts [1].

During this time the literary teacher is still fixated on the assessment and purpose of teaching from the cognitive perspective, while drama as a work of art should also reach the appreciation aspect. The purpose of this teaching should be addressed immediately. Moreover, if there is a demand for the appreciation aspect to be more emphasized in the teaching of literature (including drama) than the knowledge aspect (theory), the learning strategy must be improved.

This final result research is the product of a learning device for drama in the form of a drama book based on local art. On the basis of this description, textbooks based on local arts are very interesting to study, develop, and make into research related to the development of textbooks at LPTK.

The aims of this study are: (1) to describe the current drama lessons at LPTK, including (a) describing the current application of drama textbooks, (b) describing the needs of lecturers and students relating to the improvement of textbooks at LPTK; (2) to describe the development of local art-based drama textbooks, including: (a) describing the development of a prototype (draft) into a local art-based drama textbook based on expert judgment, (b) describing the development and improvement of local art-based drama textbooks based on limited field trials; (3) to describe the level of effectiveness of local art-based drama textbooks compared to conventional textbooks at LPTK; (4) to describe the dissemination of textbooks on local art-based drama.

\section{Methods}

\subsection{Definition of drama}

During its development, theatrical understanding changed a lot. Harymawan [2] had difficulty in finding the right formula regarding the nature of the theater in reality. His two meanings regarding the theater being divided into meanings in a broad and narrow sense do not represent the meaning of the theater. In a broad sense, the theater is described as all forms of spectacle shown in front of many people, such as ketoprak, wayang orang, ludruk, reog, dagelan, acrobatics, and so on. In a narrow sense, the theater is defined as drama, the story of human life described on stage, watched by many people, with the media of conversation, motion, and behavior, with or without 
a screen, based on a written text (literary arts) with or without music, singing, and dancing.

In a broad sense, the meaning is in line with the three opinions already outlined, while the meaning described in the narrow sense seems to contain doubt so there are many restrictions that tend not to support the previous understanding. Which can be taken from that sense is the effort of Harymawan in associating theater with drama as much peeled by the expert.

Basically, the theater cannot be separated from the drama. Indeed, the two terms are often confused because the clutter between the two is difficult to sort. There are some opinions that simply state that the theater refers to the venue or performances in their own right, while drama refers to the action of people on stage. The sorting is still too shallow regardless of the nature of the differences and the similarities between them.

Rahmanto and Adji [3] draw conclusions about the definition of drama and theater as follows: In the most general sense, drama is any work made to be staged on stage by actors depicting a life story and human life told with motion and behavior, while theater is another term for "drama" in a broader sense, including performances, audiences, and a theater.

Drama is defined as that mode of fiction designed for stage representation and constructed according to the particular dramatic convention, sedangklan theater diartikan sebagai, with the production and communication of meaning in the performance itself and with the systems underlying it.

According to Riantiarno [4], drama comes from the Yunani draomai and dran, meaning to act. Today, the definition of drama is more related to literary works. It can also mean "play script."

\subsection{Drama lessons}

According to Waluyo [1], the learning of drama at school can be classified into two groups, namely: (1) the learning of drama texts including literature, and (2) staging drama, which belongs to the theater. In drama text lessons, performance is recommended, even if one semester may only include two or three simple performances. In staging drama, the staging of class drama (for demonstration) and performances for the school watched by all students in the school are the first kinds of performances performed by Indonesian teachers, while the second types of performances are usually 
performed by the school theater group or with the cooperation of Indonesian teachers, schools, and Student Board Executive.

The difficulties in learning drama at the school include:

1. The lack of a dedicated coach or director.

2. A shortage of drafts and themes relevant to school demands.

3. A lack of dedicated participants.

4. The lack of a performance stage.

5. A lack of funds for training and staging.

6. A lack of technical and artistic staff.

\subsection{Learning media}

A learning tool is a set of teaching materials that can be used by teachers and students when implementing learning in the classroom. Learning devices are prepared and used by teachers with a view to facilitating the implementation of learning in the classroom so that it is expected to achieve the goals of competence. The learning tools in this study include: (a) instructional design, (b) student books, (c) LKM, (d) lecturers' handbooks, and (e) assessment guidelines.

\subsubsection{Learning design}

The instructional design was the first product of the defense tool in this study. The term "instructional design" is used in this study because it is considered more suitable. In the Big Indonesian Dictionary "design" is defined as "frame form, the pattern".

As a learning design, instructional design is a plan that describes procedures and organizing learning to achieve a basic competency set out in the Content Standards and has been described in the syllabus. The broadest range of instructional designs includes one basic competency consisting of one or more indicators for one or more meetings. Based on Government Regulation Number 19 the Year 2005 article 20, learning design contains, at least, components of learning objectives, learning materials, learning methods, learning resources, and assessment of learning outcomes. 


\subsubsection{Student books}

The student book is one of the learning tools prepared for students. There are several terms used to refer to student textbooks. Because it is used to carry out learning in the classroom, it is called the textbook (lesson). Textbooks are usually independent, meaning that students can study independently with a view to it being systematic and complete. Student books are also called "textbooks," and are books written and designed in accordance with the principles of learning, and in accordance with the order of systematic discussion, explaining the purpose of learning to be achieved, motivating students to learn, providing training, providing a summary, and oriented toward students individually. Textbooks as books designed for use in the classroom, carefully prepared by certain experts or experts in a particular field for the purposes and objectives of the lesson [5]. Thus, textbooks are one of the learning tools that can be used in schools to support the learning program.

There are advantages in the existence of textbooks, that is, they can organize and plan learning activities according to the level of learning as detailed [5]. The advantages of textbooks include: (1) the fact that they can be studied individually so that the learning agreement, (2) the opportunity to repeat or review it, (3) the possibility of checking memories, (4) the opportunity to record the next user, and (5) the specific opportunity that can be displayed by visual means to support the learning effort.

The role of textbooks is: (1) to reflect a strong and modern viewpoint of learning and modernize the application of instructional material presented; (2) to present the subject matter; (3) to take into account grammatical aspects in accordance with the students' abilities; (4) to show relevance to other subjects; (5) to provide grammar notes, avoiding vague concepts; (6) to provide stability and emphasis on the values of children and adults; (8) to appreciate students' personal differences in the use of information which will only occur when the books studied are meaningful to the reader because they can connect learning activities with previous experience and upcoming learning activities [5].

\subsection{Method}

\subsubsection{Type of research}

The topic of this research is a textbook of local art-based drama. Based on the objective of the development of a drama learning model as part of the curriculum in Program 
Studi Pendidikan Bahasa dan Sastra Indonesia (PBSI) or Indonesian Language and Literature Education Study Program and the teaching and learning process, this research includes education research. Viewed from the perspective of the activities and objectives of the research, namely the development of textbooks or the improvement of the quality of textbooks that are available so that they can be accounted for empirically, this study is categorized into research development or in-depth research and development or research-based development [6].

\subsubsection{Research procedures}

The research and development stages developed by Gall et al. [6] include product development, on-site product trials, and product improvement steps based on input or data obtained after the product is tested in the field.

This research is carried out in the following four stages: (1) preliminary study or exploration, (2) prototype development stage, (3) prototype or experimental testing stage, and (4) product introduction or application or dissemination.

\section{Results}

Basically, this research is based on the research procedure of Gall et al. [6], which includes product development, product trial in the field, and lah repair product based on input or data obtained after testing in the field.

\subsection{Preliminary stage}

\subsubsection{Aim}

The preliminary stage of this research is in the form of an exploratory study to obtain a more sexual description of the drama textbooks used so far and the effectiveness of their use.

The purpose of this stage is to describe and explain the implementation of drama textbooks for students and the need to improve the quality of learning drama for students, including:

1. Describing the quality of learning drama for current students.

2. Describing the use of current drama textbooks. 
3. Describing the needs of lecturers and students related to the improvement of drama textbooks used by students.

\subsubsection{Data and data sources}

This exploratory research data comprises information about the subject of textbooks that have been used in college and their effectiveness in the achievement of drama skills. This data is collected from the following sources.

1. Drama lecturers at several LPTKs in the ex-residency of Madiun namely Madiun city, Ngawi Regency, and Ponorogo regency. Selected learning activities at several LPTKs based on the diversity of the drama textbooks used.

2. Analysis of documents, including textbooks, syllabuses, instructional materials, teaching models, instructional media, teaching plans, assessment tools, and other relevant documents.

\subsubsection{Data collection techniques}

1. In-depth interviews with resource persons. Interviews focused on the scope of textbooks to be explored to reveal all issues related to textbooks and their implementation or use in the classroom.

2. Class observation or passive observation (nonparticipant observation). Observations are conducted to understand the application of the development of learning experiences based on the drama books used. Observations were also carried out to determine the suitability or gap between what the researcher believes and what happens in practice in the field.

3. The analysis of collected documents is related to drama textbooks that have been used at LPTKs. All documents, either formal (curriculum, syllabus) or nonformal (drama learning book, drama learning model, or student activity sheet), are examined to obtain a complete picture of the need for the application of drama textbooks at LPTK.

4. The questionnaire, used for collecting data from unreached resource persons with interviews, especially students or some lecturers at LPTK. 


\subsubsection{Data analysis}

The data collected in this research is nonnumerical data in the form of behavior and speak the language. So, a qualitative data analysis is performed. The procedures suggested by Miles and Huberman [7] are: (1) data collection (focusing on the collection of data); data analysis (analysis during data collection, within-site analysis, crosssite analysis); (3) data presentation (matrix displays some general suggestions); (4) drawing and verifying conclusions. The analysis is continued by drawing conclusions based on themes that are the focus of exploration.

\subsection{Model development stage}

\subsubsection{Aim}

The purpose of this phase is to develop a drama-based textbook based on local art that includes:

1. Describing the results of prototype development (draft) in a drama textbook based on expert judgment.

2. Describing the results of the development and improvement of the prototype (draft) of the book into a textbook of local-based drama based on a limited trial in the field.

\subsubsection{Trial procedure}

1. Planning phase. Planning prototype (draft) textbooks with local arts-based drama embodied in the form of a prototype syllabus for drama learning at LPTK are poured into the SAP. Preparation of a prototype textbooks drama with local artsbased is developed together with lecturers. Through this activity will be obtained input and suggestions for the refinement of the prototype (draft) textbooks drama with local arts-based.

2. Action. The drama lecturer as a partner tries the prototype textbooks with local arts-based drama to be applied in the classroom. 
3. Evaluation. Monitoring and evaluation activities are conducted by observing the course of classroom learning to reveal the weaknesses and effectiveness of prototype textbooks with local arts-based drama. The indicator used is the achievement of KD with respect to the defined drama learning model. Evaluation is based on the observation, understanding, and reflection of the researcher. The results are discussed with collaborators, lecturers, and experts in the form of focus group discussions.

4. Improvements. Based on observations, inputs from resource persons, and evaluation results, prototypes of local art-based drama textbooks were improved to minimize deficiencies and optimize the benefits of drama textbooks that have been prepared. The improvement process involves collaborators who are involved in trials and experts in textbooks and drama lessons at LPTK, who participate in providing input to locate local art-based drama textbooks developed at this stage. Procedures 1 to 4 can be repeated until the desired model is obtained.

\subsubsection{Place of study}

Experimental activities concerning local arts-based drama textbooks were held at IKIP PGRI Madiun.

\subsubsection{Research subject and researcher role}

1. Experimental activities concerning local arts-based drama textbooks were held at IKIP PGRI Madiun. The subjects of the study are the students of the Indonesian language education program that pursued a drama course determined purposively based on the academic condition of the High Institution and the learners' willingness. The intended academic condition is that the subject of lecture study at a qualified institution is equally good regarding the implementation of the curriculum, lecturers, students, and other learning facilities, even though the status of the institution is different. Lecturers are essential, especially lecturers whose institutions are used for limited trials and broader trials; lecturers act as partner lecturers who will carry out learning in addition to their role as primary speakers and colleagues in the discussion.

2. The role of the researcher is as an observer in the learning process that implements the prototype of the specified drama textbook. 
3. The partner lecturer plays two important roles at the same time as the executor of prototype testing of drama and as a primary speaker who is involved from the beginning of the research to the assessment and provides input on the textbooks being piloted. The consideration is because of the lecturers of partners who use this textbook so that input and involvement of the lecturers of partners very determine the success of apple value model of learning in the real classroom drama.

\subsection{Model testing stage}

1. Aim

The model testing phase aims to determine the effectiveness of textbooks based on local arts, including:

(a) Comparing the drama textbooks used by using local art-based drama textbooks and old/conventional textbooks based on pretest value.

(b) Describing the differences between drama textbooks that are used by using local art-based drama textbooks and conventional textbooks based on posttest value. Based on this posttest value analysis, it is known that the effectiveness of textbooks based on local arts in facilitating and accelerating the mastery of dormitory ability as expected in the curriculum compared with the old/conventional textbook used in LPTK.

2. The method used

The method used in model testing is the experimental method. The design used for model testing experiments is a static group comparison design, one of the designs suggested by Fraenkel and Wallen [8]. In this design, there are two experimental groups, namely the control group and the experimental group, which are both given a pretest. Furthermore, the control group used a drama textbook that has been used (conventional), while the experimental group used drama textbooks based on local art. At the end of the treatment, both groups were given a final test (posttest) and compared. The difference in scores between the pretest and posttest of the two groups (gain scores) was compared to measure the difference in the achievement of both drama groups.

3. Population and sample

The population of this research model testing is the students of PBSI at LPTK in the Madiun residency. LPTKs in Madiun include IKIP PGRI Madiun and Unika Wima 
Madiun. In Ngawi district there is STKIP PGRI Ngawi and in Ponorogo Regency STKIP PGRI Ponorogo.

The number of samples for testing the local art-based drama-learning model is four LPTKs. The sampling technique used is purposive sampling. The characteristics of the selected sample need to be known in advance by way of a preliminary study so that the selected sample is relevant to the objectives and research problem. Moleong [9] states that decisions on sample determination, magnitude, and sampling strategy basically depend on the unit of study. Sometimes individual study units are used such as students, lecturers, captains, and so on.

\section{Data collection technique}

The data were collected by using a checklist concerning the ability of dormitories filled with lecturers, as well as instruments in the form of student dormitory tests. The test is given before treatment (pretest) and after treatment (posttest) with the same material. The test is prepared by taking into account the good test criteria and suitable for students PBSI, especially in relation to the validity and reliability. These two tests are given to reveal the results of the acquisition of drama learning ability after using two drama textbooks, namely local art-based drama textbooks (in the experimental group) and conventional drama textbooks used by drama course lecturers during this time (in the control group).

\section{Place of research}

The place of research was the LPTK for the ex-Madiun. LPTKs in the entire Madiun area include Madiun, Ngawi, and Ponorogo.

6. Instrument validity and reliability

In accordance with the objectives and subjects of the study, the validity of the test instrument is checked by using the conformity between the item and the curriculum content of the PT (content validity), and its compatibility with the competence construct of student drama competence that will be developed through the drama textbook [10].

The validity of the content refers to the notion of whether the test kit aligns with the purpose and description of the instructional materials taught. If the test items are clearly intended to measure a particular objective and are representative of the material being taught, the test will have the validity of the content. Objectives and lesson materials usually Returned or based on the curriculum, then this type of validity is also called "curricular validity" [11]. 
A validity test is done by calculating the correlation coefficient ( $r$ count) between the grain score and the total score, then comparing with the r table value at the 0.05 significance level. If the value of r count $\geq$ r table the test item is declared valid, but if the value of r count $<r$ table then the test item is declared invalid.

Meanwhile, a test is said to be reliable if it can measure consistently something that will be measured over time [11]. Nurgiyantoro further explains that a consistent understanding of the test confidence is related to three things: (1) the test can give a relatively fixed result to something measured, (2) each student's answers to the test items are relatively fixed, and (3) test results checked by anyone will also produce approximately the same score.

Since the drama test items in this study are expressed in the form of gradation $(1,2,3,4,5)$, the instrument reliability coefficient is calculated by using the Cronbach's alpha formula [12]. To avoid counting errors, validity and reliability tests are performed with the help of the computer program SPSS version 19.0.

\section{Data analysis technique}

To test the effectiveness of local art-based drama textbooks, final student test results were taught using local art-based drama-based learning models compared to the final student test results taught using conventional models. However, before treatment was given, both groups were given a pretest with the objective of knowing whether the control group and the experimental group had a balanced initial ability or not using the Equilibrium/Equalization Test.

Because the initial test data and the final test data are not internal data (numeric scale) but in the form of category data (gain score), the data analysis technique used for the balance test (preliminary test data) and model testing (final test data) was the chi-squared test $\left(X_{2}\right)$. conceptual, engineering chi-squared $\left(X_{2}\right)$ was used to test whether there is a real difference between the actual number of students (fo = observation frequency) and the number of students theoretically (fe = expected frequency) in each category (not achieving indicators, already reaching indicators, and exceeding indicators) in the control class when compared to the experimental class.

Equality or equilibrium with a significance level of $5 \%$ was tested by analyzing the results of a pretest to prove that students taught using a drama-based learning model based on local arts and students taught by using conventional learning models have the same level of prior knowledge. The hypotheses are as follows: (a) Ho: there is no difference in the initial ability of students between classes taught using a drama learning model based on local artistry and those taught using the conventional model; 
(b) $\mathrm{H}_{1}$ : There is difference beginning of classes taught using learning model drama based Local arts with those taught using conventional models.

The effectiveness of the learning model based on local arts drama is tested by comparing the results of the (posttest) students taught using the drama-based learning model with the local arts and those taught using the conventional model with a significance level of $5 \%$ or 0.05 . The hypotheses to be proved are (a) Ho: There is no difference in the final test results between classes taught using the learning model and conventional drama models; (b) $\mathrm{H}_{1}$ : There is a difference in the final test results between classes taught using the drama learning model based on local art and those taught using conventional models.

\subsection{Dissemination phase}

The dissemination phase aims to introduce or disseminate the product by publishing a manual for a learning model of local art-based drama, especially for stakeholders. Through the dissemination of products by way of publication the stakeholders are expected to:

1. Obtain the use of local art-based drama learning models.

2. Obtain the skills required to apply local art-based drama learning models at LPTK.

Teaching materials are a key part of learning resources. The definition of learning resources is states that one component of learning resources is the material [13]. The material is software that contains learning messages, which are usually presented using certain equipment. Examples of such teaching materials are textbooks, modules, films, transparencies ( $\mathrm{OHT}$ ), audio cassette programs, and video programs. The teaching materials are equated with the teaching materials as they are based on the literal meaning of materials in English. Similarly material in English also means material. As stated by Kim, teaching materials or instructional materials are broadly composed of skills and attitudes that students must learn in order to achieve a defined standard of competence. Permendiknas no. 41 of 2007 stated that teaching materials contain relevant facts, concepts, principles, and procedures, and are written in the form of items in accordance with the formulation of indicators of achievement of competence. So, it can be concluded that teaching materials are a part of learning resources that consist of knowledge, skills, and attitudes or software containing instructional messages presented using certain equipment. 
Teaching materials based on the technological sophistication used are divided into four types. These teaching materials include printed materials, audio, audiovisual, interactive multimedia, and web-based teaching materials. Printed teaching materials include teaching materials printed on sheets such as textbooks, modules, handouts, worksheets, brochures, leaflets, etc. Audio teaching materials include cassettes, radio, LPs, and audio compact discs. Audiovisual teaching materials include video compact disks and movies. Interactive multimedia teaching materials include CAI (ComputerAssisted Instruction), compact disks (CDs), interactive learning multimedia, and webbased learning materials.

Based on the types of teaching materials above, textbooks are a part of printed or written teaching materials. The textbook is a book prepared for the learning process either derived from the results of research or the result of a thought about something or study of a particular field that is then formulated into learning materials. Tarigan [5] states that textbooks in a particular field of study are compiled by experts in the field and used to support learning. Akbar [14] states that textbooks are used as standard references for a certain subject matter.

Komalasari [13] states that textbooks in a particular field of study are standard books composed by experts in the field with instructional intent and purpose, complemented by harmonious learning tools that are easily understood by the users in schools and colleges so as to support a learning program.

Learning materials are components of the curriculum that must be submitted to the students. These components have diverse message forms, including facts, concepts, principles/rules, procedures, problems, and so forth. They serve as the content or material that must be mastered by students in learning activities. The scope of learning materials has been arranged systematically in the organizational structure of the curriculum, in this case as the standard content.

The material in the standard content is only the subject matter, so for $t$ smooth implementation of learning, learning materials need to be developed first by completing it in the form of learning materials intact. At the time of implementing learning, a professional educator needs to understand the characteristics of the learning message to be delivered, so as not to choose the wrong learning materials.

In developing learning materials it is necessary to consider the development models to ensure their quality, as revealed by Sagala (2005, p. 136). The use of a learning materials development model that systematically develops teaching in accordance with the theory will ensure the quality of the content of learning materials. The models 
include the ADDIE, ASSURE, Hannafin and Peck, Gagne and Briggs, and Dick and Carry models. A number of these several models need to be more deeply understood.

\section{References}

[1] Waluyo HJ: Drama: Teori dan pengajarannya [Theory and teaching]. Yogyakarta : Hanindita Graha; 2006.

[2] Harymawan RMA: Dramaturgi. Bandung: PT Rosda Karya; 1993.

[3] Rahmanto B, Adji SEP: Drama. Jakarta: Universitas Terbuka; 2011.

[4] Riantiarno N: Kitab teater [Book of the theater]. Jakarta: Grasindo; 2011.

[5] Tarigan HG: Pengajaran kosakata [Vocabulary teaching]. Bandung: Angkasa; 1989.

[6] Gall MD, Borg WR, Gall JP: Educational research: an introduction. United Kingdom: Longman Publishing; 1996.

[7] Miles MB, Huberman AM: Qualitative data analysis, a sourcebook of new methods. London: SAGE Publication; 1984.

[8] Fraenkel JR, Wallen NE: How to design and evaluate research in education. New York: McGraw Hill; 1990.

[9] Moleong LJ: Metodologi penelitian kualitatif [Qualitative research methodology]. Bandung: PT Remaja Rosdakarya; 2005.

[10] McMillan JH, Schumacher S: Research in education: a conceptual introduction. New York: Little Brown; 1984.

[11] Nurgiyantoro B: Penilaian dalam pengajaran bahasa dan sastra [Assessment in language and literature teaching]. Yogyakarta: BPFE; 2009.

[12] Azwar S: Penyusunan skala sikap [Preparation of attitude scale]. Yogyakarta: Pustaka Pelajar; 1999.

[13] Komalasari K: Pembelajaran kontekstual: konsep dan aplikasi [Contextual learning: concepts and applications]. Bandung: PT Refika Aditama; 2012

[14] Akbar S: Pengembangan kurikulum dan pembelajaran ilmu pengetahuan sosial [Development of curriculum and social science learning]. Yogyakarta: Cipta Media; 2011.

[15] Sagala S: Konsep dan makna pembelajaran [Concepts and meaning of learning]. Bandung: CV Alvabeta; 2005. 